\title{
ANALYSIS OF VARIATIONS IN AIR POLLUTION FIELDS IN SELECTED CITIES IN POLAND AND GERMANY
}

\author{
ANALIZA ZMIAN POLA IMISJI ZANIECZYSZCZEŃ POWIETRZA \\ W WYBRANYCH MIASTACH W POLSCE I W NIEMCZECH
}

\begin{abstract}
Variations in immission fields resulting from emissions and pollutant dispersion in the atmosphere were investigated. The analysis was based on data from the four-year period covering the years 2012-2015, collected in two automatic atmospheric air monitoring stations, one located in Germany in Magdeburg which is the capital of Saxony-Anhalt and the other in Poland in Lodz, i.e. the seat of Lodz Region authorities. Selected immission monitoring stations in both cities are located in the areas with similar urban development and are characterized by high levels of pedestrian and car traffic. In both measuring stations the following atmospheric air pollutants were measured: PM10, sulfur dioxide, nitrogen oxide and nitrogen dioxide, and ozone (carbon monoxide was analyzed only for the station located in Lodz). On the basis of the measured data the periodic exceedance of air pollution limit values measured at both monitoring stations were observed, as well as the levels of particular pollutants and changes in immission fields were analyzed. It seems that this information may be useful not only to the competent authorities of the country but also to the users of these areas.
\end{abstract}

Keywords: air pollution, immission field, pollutant variation and distribution

\section{Introduction}

As a result of emission processes and subsequent dispersion in the atmosphere, a specific distribution of pollutant concentrations is formed on the earth surface. The immission level is estimated at a given point and time, and all immission measurements are reported as pollutant concentrations, averaged over appropriate time periods, and are used to determine the quality of atmospheric air. Therefore, any analysis of changes in the field of pollutant immission in a given area may be useful in monitoring the atmosphere and should be periodically or continuously carried out and continually improved. Monitoring of the atmosphere is based on the recording of physical and chemical characteristics of the atmosphere, significant from the health and economic point of view, and should be implemented on a regular and continuous basis [1-4].

\footnotetext{
${ }^{1}$ Faculty of Architecture, Civil and Environmental Engineering, Lodz University of Technology, al. Politechniki 6, 90-924 Łódź, Poland, phone +48 4263120 20, fax +48 4263135 16, email: robert.cichowicz@p.lodz.pl

${ }^{2}$ Faculty of Process and Environmental Engineering, Lodz University of Technology, ul. Wólczańska 175, 90-924 Łódź, Poland, phone +48 4263137 95, fax +48 4263681 33, email: grzegorz.wielgosinski@p.lodz.pl

*Corresponding author: robert.cichowicz@p.lodz.pl
} 
It should be remembered that the monitoring of physical characteristics of the atmosphere was developed only in the $19^{\text {th }}$ century and was based on the measurement of pressure, temperature, humidity, wind speed and direction. Its aim was to track the weather and predict its changes $[5,6]$. On the other hand, monitoring of atmospheric pollution with harmful substances has developed only in the second half of the $20^{\text {th }}$ century and is now called air quality monitoring. This monitoring helps to plan rational measures of air pollution prevention and to assess the impact of the actions taken [7-10].

This is particularly important because of the high impact of energy industry impact, which emits enormous amounts of pollutants as a result of burning fossil fuels [11-13] and due to the ever-increasing number of motor vehicles, with limited road infrastructure. In addition, the variability of air pollution in time and space is especially visible in large cities and traffic junctions [14-16]. According to [17], this variability is determined by changes in the amount of pollutant emissions and changes in the conditions in which these pollutants are dispersed in the atmosphere, and the dispersion dynamics is shaped by the variability of meteorological conditions, atmospheric circulation and the vertical gradient of air temperature. At the same time, it should be borne in mind that the level of air pollutants depends both on the variable economic activity as well as on the daily, weekly, monthly and seasonal changes in emissions to the atmosphere [18-20].

The scale of the problem is best illustrated by the reports published by the European Environment Agency (EEA), which show that both Germany and Poland (together with England) generate the highest $\mathrm{NO}_{\mathrm{x}}$ emissions from large combustion plants. The emissions from Germany are largely in line with IED ELV, with the minimum emission limit values in accordance with the 2010/75/EU Directive [21]. On the other hand, according to IED ELV Poland, next to Greece, Spain and Great Britain, still has the highest absolute $\mathrm{NO}_{\mathrm{x}}$ differences calculated in $\mathrm{Mg}$ (tonnes), and in the case of sulfur dioxide and particulate matter Poland is among countries emitting the highest amounts of these pollutants [22].

In addition, in large cities, traffic is a major source of atmospheric pollution, which may cause an increase in emissions in some areas of the city, e.g. CO by $70-90 \%$, and $\mathrm{NO}_{\mathrm{x}}$ by $23 \%$. This is due to the ever-increasing volume of traffic that results in traffic jams which increase vehicle emissions (carbon monoxide, nitric oxide, hydrocarbons, lead compounds and soot). This is especially dangerous in the areas where building conditions prevent the spread of pollutants [23].

According to a report of the European Environment Agency (EEA) [24] of 2013, emissions of major pollutants in Europe between 2002 and 2011 have decreased, resulting in improved air quality throughout the Union. In certain sectors, there is some increase in emissions, for instance suspended particulate matter in fuel combustion in the commercial, institutional and household sectors, which increased by about $7 \%$. On the other hand, in the case of $\mathrm{SO}_{2}, \mathrm{CO}$ and $\mathrm{Pb}$ emissions, a significant reduction was observed which unfortunately did not translate into a decrease in the concentration of these pollutants in the atmosphere as well as $\mathrm{PM}$ and $\mathrm{O}_{3}$.

\section{Characteristic of the tested area}

As each of the environmental monitoring system in Poland and Germany depends primarily on the degree of pollution of the area and population density, it is important to first analyze this type of information. For example, in central Poland, there are about 2.5 million inhabitants in the Lodz Region on the area of about $18220 \mathrm{~km}^{2}$ and population 
density of 136.6 inhabitants $/ \mathrm{km}^{2}$, while in central Germany in Sachsen-Anhalt 2.3 million inhabitants on the area of about $20450 \mathrm{~km}^{2}$ and at population density of about 111 inhabitants per $\mathrm{km}^{2}$. Although the main cities of both regions/lands, i.e. Lodz (with the area of $293 \mathrm{~km}^{2}$, population of about 695 thousand, population density of about 2350 inhabitants $/ \mathrm{km}^{2}$ ) and Magdeburg (the area of $201 \mathrm{~km}^{2}$, population of about 240 thousand, population density of about 1200 inhabitants $/ \mathrm{km}^{2}$ ), vary in size and number of inhabitants, they are exposed to similar phenomena affecting the quality of atmospheric air (both cities are important junctions for road and rail transport).

This analysis was based on data from the four-year period covering the years 2012-2015, obtained from two automatic atmospheric air monitoring stations located in Lodz, Poland (Fig. 1) which is the seat of Lodz Region authorities, and in Magdeburg, Germany (Fig. 2) which is the capital of Saxony-Anhalt.

In Poland air quality is controlled within the regional air quality assessment systems, which are supervised by the Regional Inspectorates for Environmental Protection. In Germany, the air monitoring network is run and controlled by the German Federal Environment Agency which collects information from each network in the respective federal states.

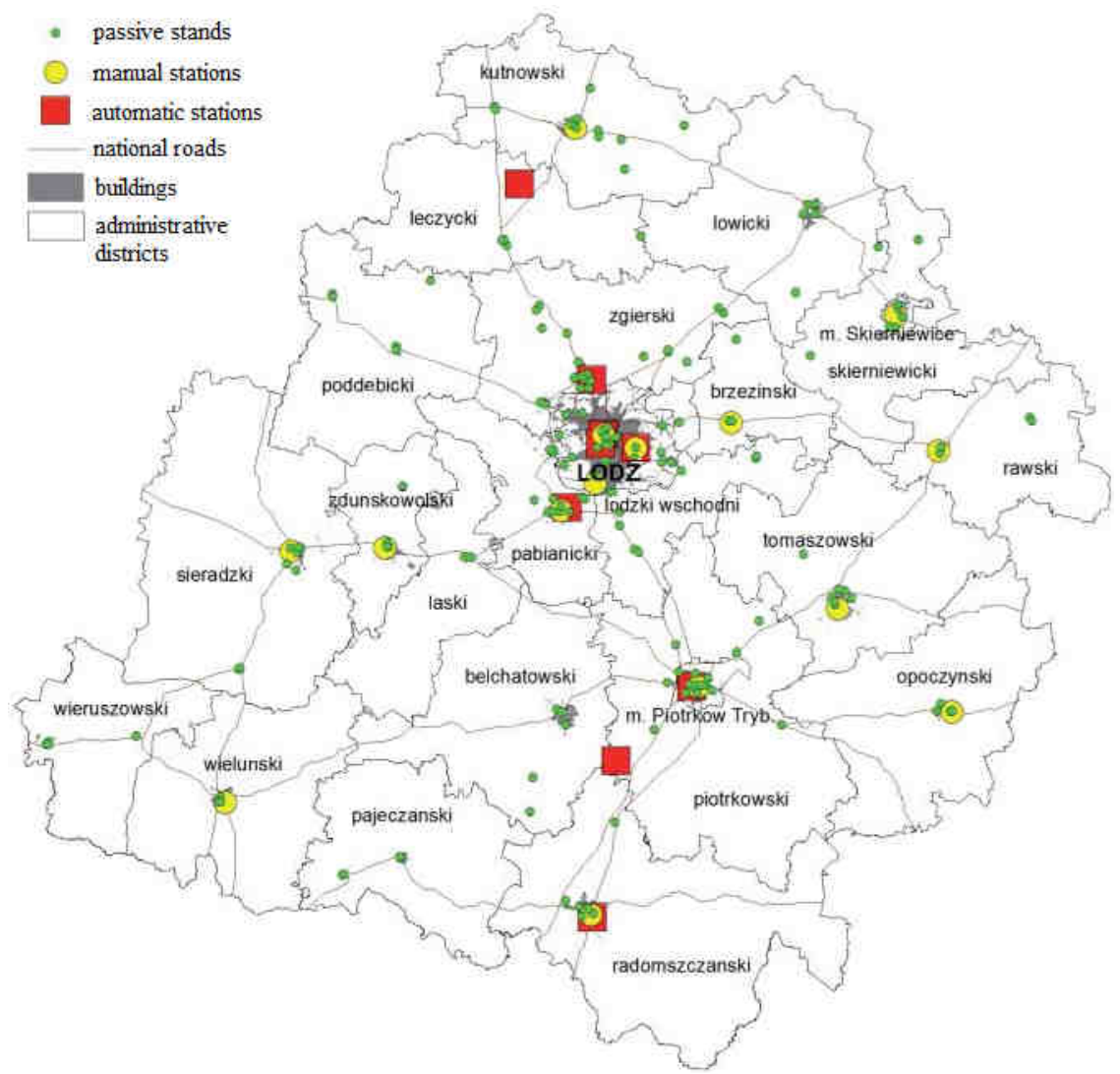

Fig. 1. Air quality monitoring network in Lodz Region in 2013 [25] 


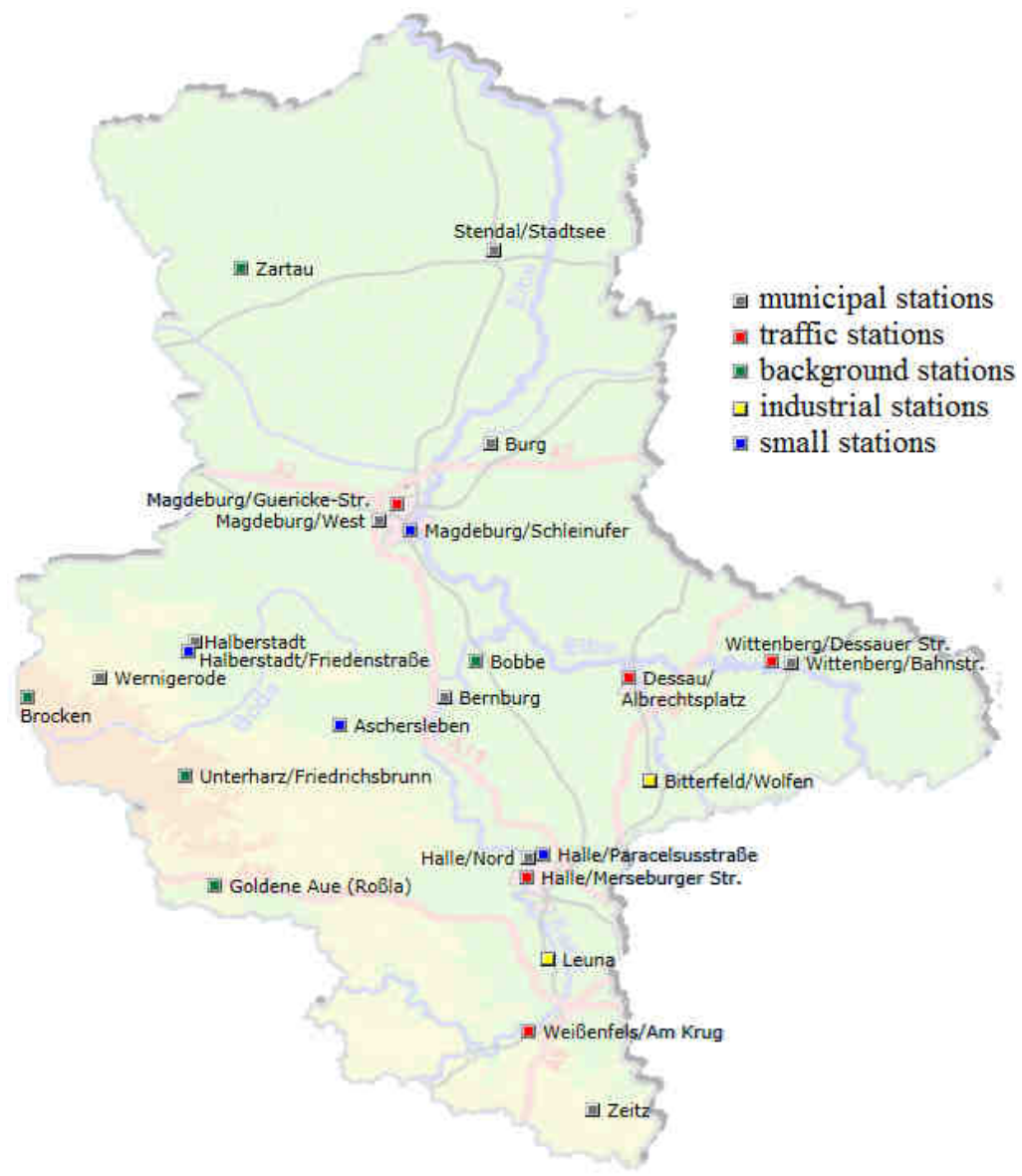

Fig. 2. Location of measuring stations in Sachsen-Anhalt in Germany [26]

The measuring station in Lodz, Poland is located at 16, Gdanska Str. (Fig. 3). It is equipped with analyzers for continuous measurement of such pollutants as $\mathrm{PM} 10, \mathrm{SO}_{2}, \mathrm{NO}$, $\mathrm{NO}_{2}, \mathrm{O}_{3}$ and $\mathrm{CO}$ and benzene, $\mathrm{NO}_{\mathrm{x}}$ and PM2.5 (the last three are not subject to the following analysis). All measurements are based on reference methods recognized by the European Commission [27]:

- for PM10 this is the weakening of beta radiation (the method equivalent to the reference method);

- for $\mathrm{SO}_{2}$, this is ultraviolet fluorescence conforming to the PN-EN 14212:2013-02 (EN 14212:2012) method [28];

- for NO and $\mathrm{NO}_{2}$ this is chemiluminescence, according to the PN-EN 14211:2013-02 (EN 14211:2012) method [29];

- for $\mathrm{O}_{3}$ this is ultraviolet photometry, according to the PN-EN 14625:2013-02 (EN 14625:2012) method [30];

- for CO this is non-dispersive infrared spectroscopy, according to the PN-EN 14626:2013-02 (EN 14626:2012) method [31]. 
In Magdeburg, Germany, the measuring station is located at Hans-Loscher-Strasse 30 (Fig. 4) and similarly as in Lodz, the analyzers measure (based on the same reference methods) the following pollutants: $\mathrm{PM} 10, \mathrm{SO}_{2}, \mathrm{NO}$ and $\mathrm{NO}_{2}, \mathrm{O}_{3}$ (due to the low $\mathrm{CO}$ concentration its level has not been measured) and benzene, toluene, xylene and PM2.5 (the last four are not subject to the following analysis).

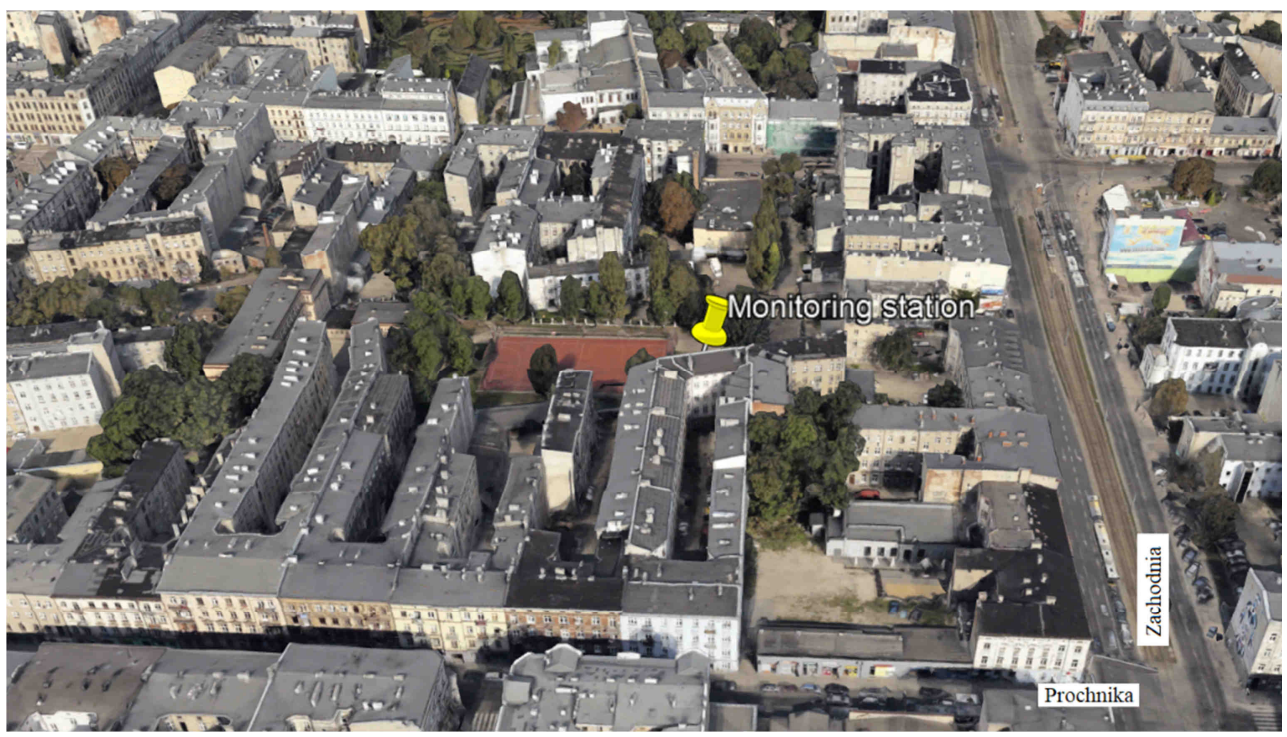

Fig. 3. Location of Lodz-Gdanska monitoring station [32]

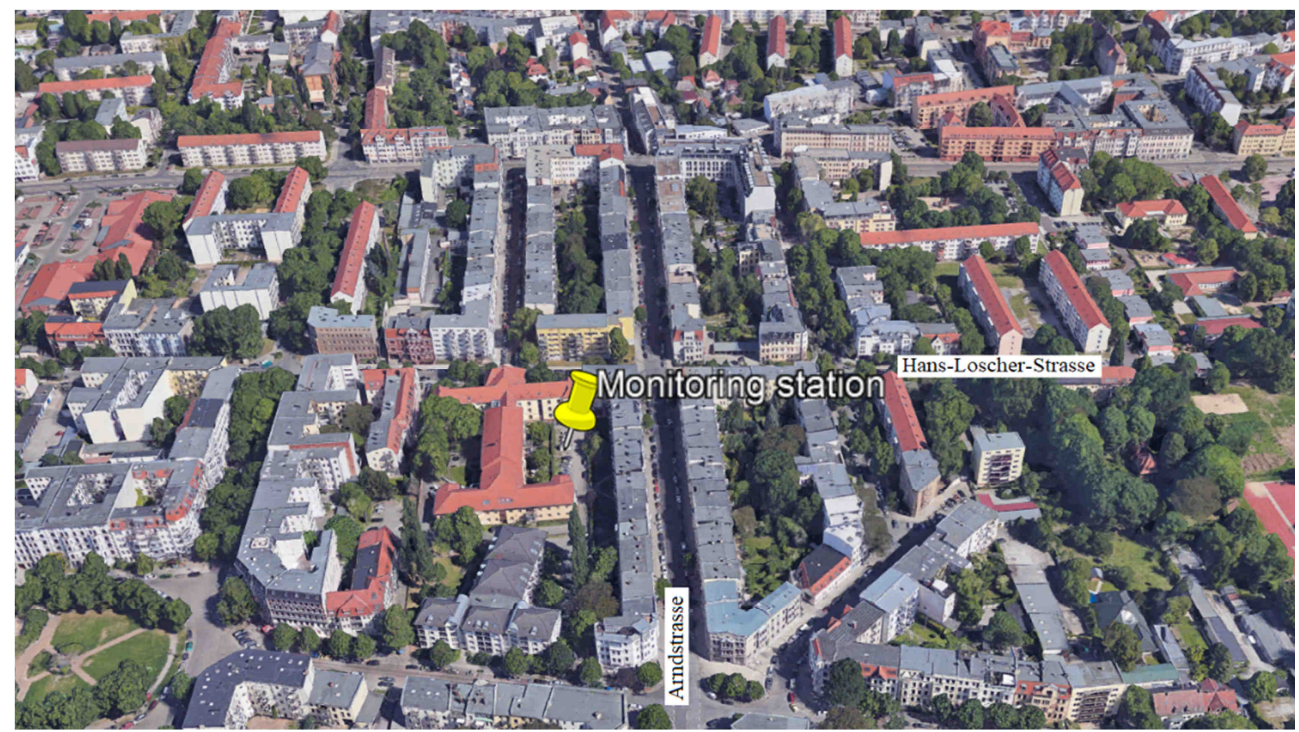

Fig. 4. Location of Magdeburg-West monitoring station [32] 


\section{Results and discussion}

Selected monitoring stations in both cities are located in the areas with similar urban development and are characterized by high levels of pedestrian and car traffic. At both measuring stations, the following atmospheric air pollutants were measured: PM10 (Fig. 5), $\mathrm{O}_{3}$ (Fig. 6), $\mathrm{SO}_{2}$ (Fig. 7), $\mathrm{NO}$ (Fig. 8) and $\mathrm{NO}_{2}$ (Fig. 9), and additionally $\mathrm{CO}$ was analyzed only for the station located in Lodz (Fig. 10).

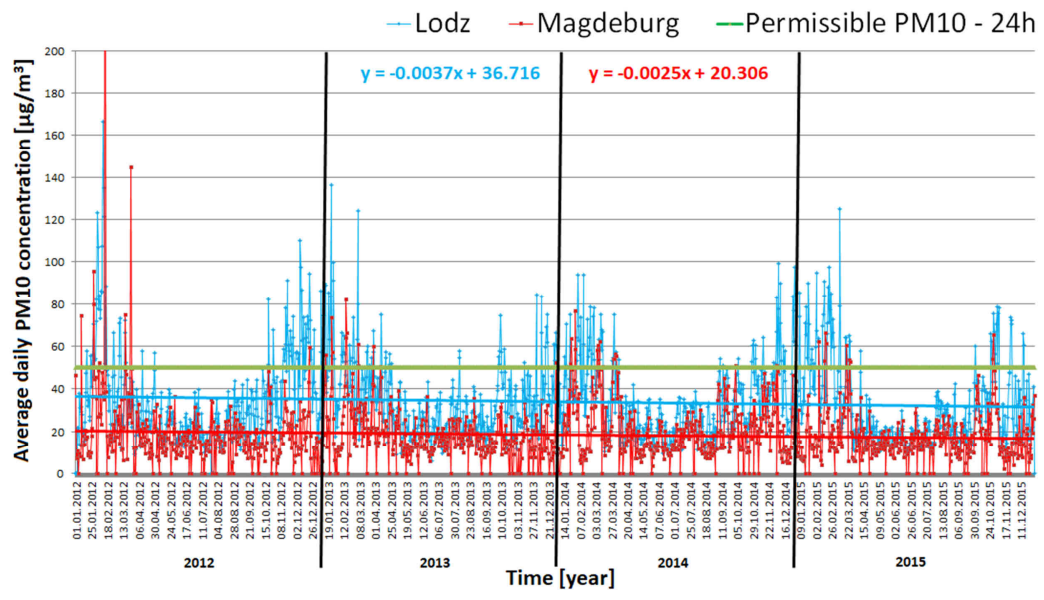

Fig. 5. PM10 concentrations in Lodz and Magdeburg

Based on data from the Lodz station, average PM10 concentration was calculated as $34.4 \mu \mathrm{g} / \mathrm{m}^{3}$ and year-on-year decrease by $3.19,0.69$ and $6.88 \%$ was observed, while in Magdeburg the mean concentration was $20.2 \mu \mathrm{g} / \mathrm{m}^{3}$ (which constituted $58.72 \%$ of the concentration in Lodz), with a decrease in 2013 and 2015 and an increase of $8.25 \%$ in 2014.

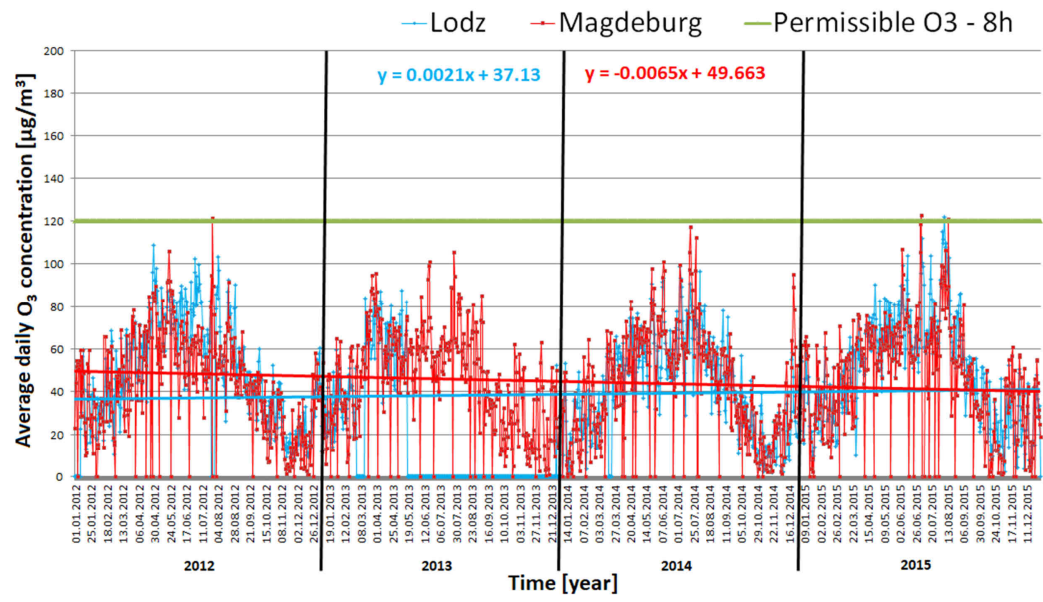

Fig. 6. $\mathrm{O}_{3}$ concentrations in Lodz and Magdeburg 
In the analyzed period the mean $\mathrm{O}_{3}$ concentration in both Lodz and Magdeburg was $47.5 \mu \mathrm{g} / \mathrm{m}^{3}$, whereas in Lodz in 2013 and in 2015 it increased by 0.82 and $19.14 \%$, respectively, and by $17.50 \%$ in 2014. In contrast, in Magdeburg it decreased by 7.10 and $5.42 \%$ in 2013 and 2014, respectively, and by $9.77 \%$ in 2015 .

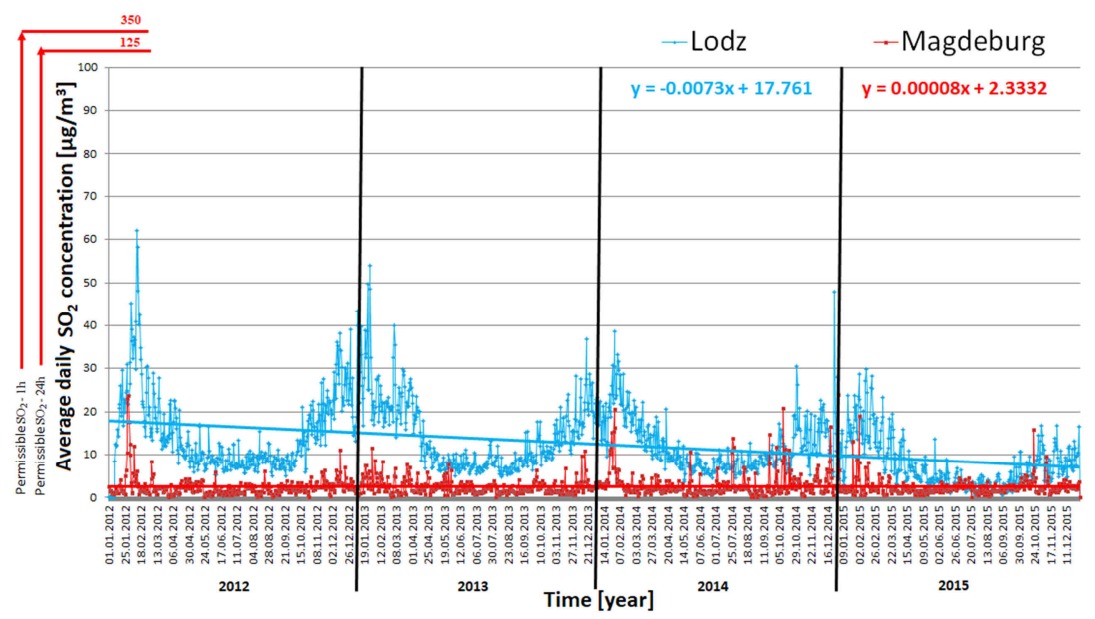

Fig. 7. $\mathrm{SO}_{2}$ concentrations in Lodz and Magdeburg

In contrast, mean concentration of $\mathrm{SO}_{2}$ in Lodz was $12.5 \mu \mathrm{g} / \mathrm{m}^{3}$ and a year-on-year decrease by 4.63, 15.63 and 37.52 \% was observed, while in Magdeburg the average concentration was $1.7 \mu \mathrm{g} / \mathrm{m}^{3}$ (which was $13.6 \%$ concentration in Lodz) and if in 2013 and 2015 it decreased by 19.86 and $13.34 \%$, respectively, in 2014 it increased by $8.35 \%$.

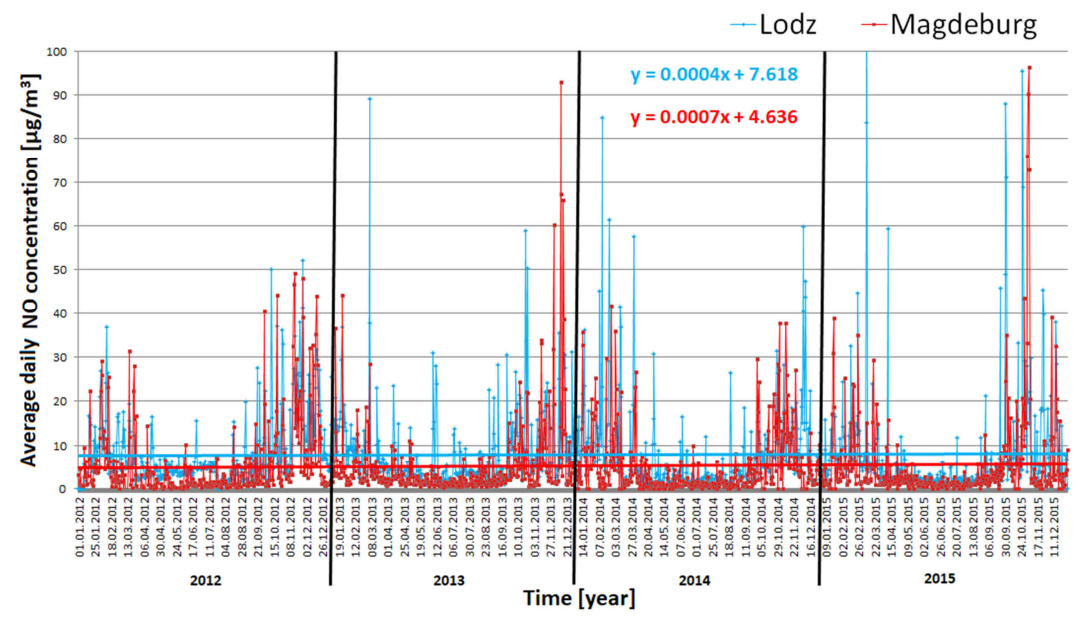

Fig. 8. NO concentrations in Lodz and Magdeburg 
The average level of $\mathrm{NO}$ in Lodz was $8.1 \mu \mathrm{g} / \mathrm{m}^{3}$ and in $2012-2014$ it decreased year-on-year by 5.70 and $2.37 \%$, respectively, while in 2015 the concentration increased by $1.84 \%$. In Magdeburg the mean concentration was to $5.4 \mu \mathrm{g} / \mathrm{m}^{3}$ (which constituted $66.67 \%$ of the concentration in Lodz) and if in 2013 it decreased by $4.75 \%$, in the years 2014-2015 it increased by 9.51 and $1.55 \%$, respectively.

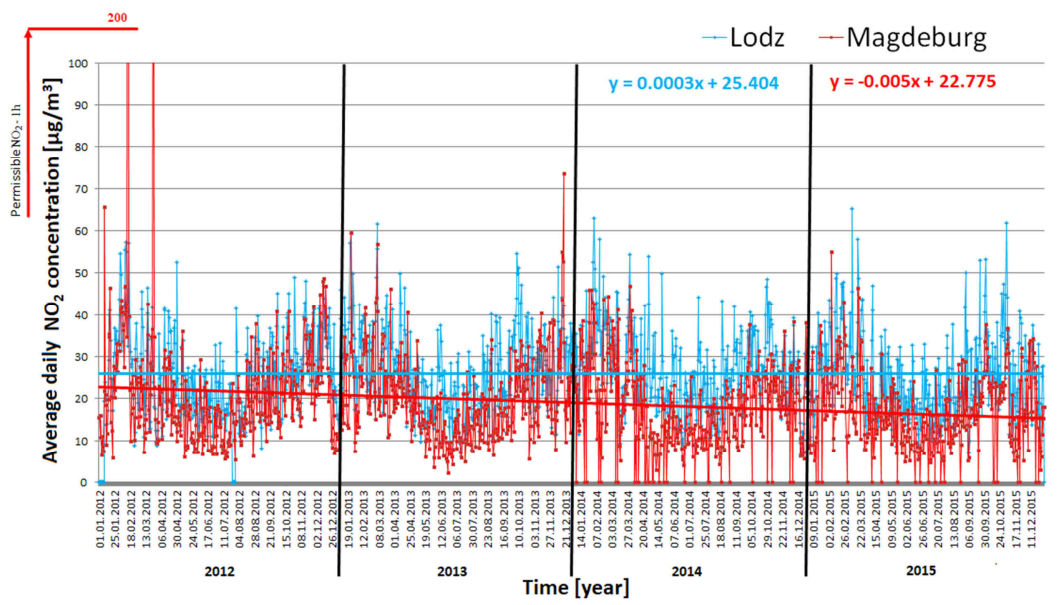

Fig. 9. $\mathrm{NO}_{2}$ concentrations in Lodz and Magdeburg

In the analyzed period the average concentration of $\mathrm{NO}_{2}$ in Lodz was $26.3 \mu \mathrm{g} / \mathrm{m}^{3}$ and in the years 2012-2014 it increased by 2.10 and $1.19 \%$, respectively, and in 2015 it decreased by $6.05 \%$, while in Magdeburg the mean concentration was $19.8 \mu \mathrm{g} / \mathrm{m}^{3}$ (which was $75.28 \%$ of the concentration in Lodz) and its year-on-year decrease was 7.87, 3.77 and $8.36 \%$, respectively.

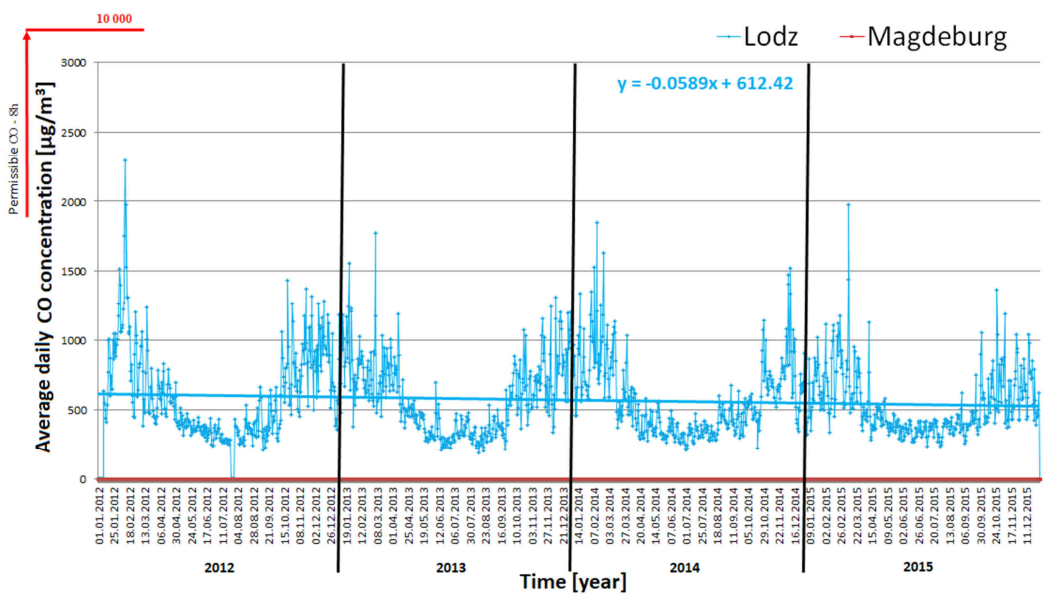

Fig. 10. CO concentrations in Lodz and Magdeburg 
In addition, based on data from the Lodz station, the mean CO concentration was calculated to be $577.0 \mu \mathrm{g} / \mathrm{m}^{3}$ and its year-on-year decrease by $6.33,0.92$ and $6.82 \%$, was reported, while in Magdeburg due to the low level of pollution in the analyzed period, its monitoring was abandoned.

\section{Conclusions}

On the basis of the measurements, periodic exceedance of atmospheric air pollutants measured at both stations was detected, and trends in the levels of particular pollutants as well as changes in imission fields were observed. It seems that this information may be useful not only to the competent authorities, but also to users of those areas.

In both cities the permissible values were exceeded first of all in the case of PM10 and occasionally for $\mathrm{O}_{3}$. The level of particulate matter was more often exceeded in Lodz (71 times in 2012, 62 times in 2013 and 2014, and 59 times in 2015) than in Magdeburg ( 8 times in 2012, 10 times in 2013, 17 times in 2014 and 9 times in 2015). Ozone values in the analyzed period were exceeded only once in Lodz (in 2015) and twice in Magdeburg (in 2012 and 2015). There were also days in which concentrations were approaching the permissible level.

At the same time it should be emphasized that changes observed in the average concentration levels of particular pollutants are not significantly different from the country-specific trend observed for European air quality [33]. Comparing the levels of particular pollutants it can be found that in the measuring station in Lodz the concentrations are higher than in Magdeburg, and thus: PM10 (by 1.70), $\mathrm{SO}_{2}$ (by 7.34), NO (by 1.5), and $\mathrm{NO}_{2}$ (by 1.33). The average level of $\mathrm{O}_{3}$ in the analyzed period is the same for both cities, i.e. $47.5 \mu \mathrm{g} / \mathrm{m}^{3}$. Additionally, the average $\mathrm{CO}$ concentration equal to $577.0 \mu \mathrm{g} / \mathrm{m}^{3}$ was also analyzed in Lodz. It systematically decreased every year by $4.69 \%$ on average.

Despite the many similarities between the analyzed cities, their geographical location and, above all, climatic conditions are different. Magdeburg is located in the North German Lowland (average height 40.6-123.8 m above sea level), while Lodz is located in the center of the Highlands of Lodz (average height 163.6-284.1 $\mathrm{m}$ above sea level). Although the wind rose for both cities is very similar, there are considerable differences in the average air temperature in individual months of the year and air humidity, despite similar average annual values. In Magdeburg, winters are definitely milder than in Lodz, while the period of high temperatures lasts longer in the summer. The sum of atmospheric precipitation is definitely (by approx. $100 \mathrm{~mm}$ ) higher in Lodz than in Magdeburg with the observed maximum in the month of July. This, of course, favors the self-cleaning of air from gaseous and dust pollutants. Climate differences may also be due to the location of Magdeburg on one of the largest European rivers - the Elbe, and in Lodz, despite the inventory of the presence of 19 rivers and smaller watercourses, their impact (due to their size) on the city's climate is negligible. In contrast, insolation, with a similar number of sunny days per year, is more evenly distributed in Magdeburg between 12 months of the year. In Lodz, there is a clear accumulation in summer, with much less sunshine in the winter.

However, it is worth emphasizing that the trends of seasonal changes in air pollution in both cities described in this paper are similar, while individual differences are most likely the result of differences in geographical location and in prevailing meteorological conditions. 
Changes observed in air quality can be related both to the development of local and global industry and to services and trade, to changes in the heat supply system, and to changes in the so-called 'urban fabric of the city', which in recent years has changed for a variety of reasons in both analyzed cities.

In addition, such analyzes may also be useful for modeling the spread of pollutants in the air as they help to identify future sources of pollutant emissions, minimize the impact of pollutants on the environment, and may be helpful in planning urban development and protection zones.

\section{Acknowledgements}

The authors would like to thank the staff of the Lodz Region Inspectorate for Environmental Protection in Poland and the employees of Luftüberwachungs- und Informationssystem (LÜSA) Landesamt für Umweltschutz Sachsen-Anhalt, Germany.

\section{References}

[1] Bellmann K, Lasch P, Straubel R. Pollutant emission control aided by the decision support system pemu/air for environmental protection. IFAC Proceedings Volumes. 1989;22(10):543-547. DOI: 10.1016/S14746670(17)53231-0.

[2] Cichowicz R, Wielgosiński G. Effect of meteorological conditions and building location on $\mathrm{CO}_{2}$ concentration in the university campus. Ecol Chem Eng S. 2015;22(4):513-525. DOI: 10.1515/eces-2015-0030.

[3] Cichowicz R, Wielgosiński G. Effect of urban traffic on the immision of carbon dioxide in the university campus. Ecol Chem Eng S. 2015;22(2):189-200. DOI: 10.1515/eces-2015-0010.

[4] Kretzschmar JG. Fifty years air pollution research and policy in the EU. Trans Ecol Environ. 2007;101(15):3-12. DOI: 10.2495/AIR070011

[5] Conner WD, Bennett RL, Weathers WS, Wilson WE. Particulate characteristics and visual effects of the atmosphere at research Triangle Park. J Air Waste Manage Assoc. 1991;41:154-160. DOI: 10.1080/10473289.1991.10466832.

[6] He F, Posselt DJ. Impact of parameterized physical processes on simulated tropical cyclone characteristics in the community atmosphere model. J Climate. 2015;28:9857-9872. DOI: 10.1175/JCLI-D-15-0255.1.

[7] Air quality trends and action plan for control of air pollution from seventeen cities. Central Pollution Control Board Ministry of Environment \& Forests India. National Ambient Air Quality Monitoring 2006; NAAQMS-29. http://cpcb.nic.in/upload/NewItems/NewItem_104_airquality17cities-package-.pdf.

[8] Alharbi BH, Pasha MJ, Tapper N. Assessment of ambient air quality in Riyadh City, Saudi Arabia. Current World Environ. 2014;9(2):227-236. DOI: 10.12944/CWE.9.2.01.

[9] Gupta AK, Gupta SK, Patil RS. Environmental management plan for port and harbour projects. Clean Techn Environ Policy. 2005;7(2):133-141. DOI: 10.1007/s10098-004-0266-7.

[10] He K, Huo H, Zhang Q. Urban air pollution in China: Current status, characteristics, and progress. Annual Rev Energy Environ. 2002;27:397-431. DOI: 10.1146/annurev.energy.27.122001.083421.

[11] Fernandez-Martinez G, Lopez-Mahia P, Muniategui-Lorenzo S, Prada-Rodriguez D, Fernandez-Fernandez E. Distribution of volatile organic compounds during the combustion process in coal-fired power stations. Atmos Environ. 2001;35:5823-5831. DOI: 10.1016/S1352-2310(01)00282-5.

[12] Guttikunda SK, Jawahar P. Atmospheric emissions and pollution from the coal-fired thermal power plants in India. Atmos Environ. 2014;92:449-460. DOI: 10.1016/j.atmosenv.2014.04.057.

[13] Li D, Guo Y, Li Y, Ding PG, Wang Q, Cao Z. Air pollutant emissions from coal-fired power plants. Open J Air Pollut. 2012;1:37-41. DOI: 10.4236/ojap.2012.12005.

[14] Chan LY, Liu YM. Carbon monoxide levels in popular passenger commuting modes traversing major commuting routes in Hong Kong. Atmos Environ. 2001;35:2637-2646. DOI: 10.1016/S1352-2310(00)00450-7.

[15] Marmur A, Mamane Y. Comparison and evaluation of several mobile-source and line-source models in Israel. Transport Res D-TR E. 2003;8:249-265. DOI: 10.1016/S1361-9209(03)00002-6.

[16] Vardoulakis S, Fisher EAB, Pericleous K. Modelling air quality in street canyons: a review. Atmos Environ. 2003;37:155-182. DOI: 10.1016/S1352-2310(02)00857-9. 
[17] Skrzypski J, Kamiński W, Jach-Szakiel E. Zarządzanie jakością powietrza i bezpieczeństwem ekologicznym jako element zrównoważonego rozwoju dużych miast. Łódź: Polska Akademia Nauk Oddział w Łodzi; 2010. ISBN: 9788386492589.

[18] Bralić M, Buljac M, Periš N, Buzuk M, Dabić P, Brinić S. Monthly and seasonal variations of $\mathrm{NO}_{2}, \mathrm{SO}_{2}$ and black-smoke located within the sport district in urban area, city of Split, Croatia. Croat Chem Acta. 2012;85(2):139-145. DOI: 10.5562/cca1966.

[19] Cichowicz R, Wielgosiński G, Fetter W. Dispersion of atmospheric air pollution in summer and winter season. Environ Monit Assess. 2017;189:605. DOI: 10.1007/s10661-017-6319-2.

[20] Lin W, Xu X, Ge B, Liu X. Gaseous pollutants in Beijing urban area during the heating period 2007-2008: variability, sources, meteorological, and chemical impacts. Atmos Chem Phys. 2011;11:8157-8170. DOI: 10.5194/acp-11-8157-2011.

[21] Directive 2010/75/EU of the European Parliament and of the Council of 24 November 2010 on industrial emissions (integrated pollution prevention and control) (Recast) (Text with EEA relevance). OJ of EU 2010;334:17-119. http://eur-lex.europa.eu/LexUriServ/LexUriServ.do?uri=OJ:L:2010:334: 0017:0119:EN:PDF.

[22] Reducing air pollution from electricity-generating large combustion plants in the European Union An assessment of potential emission reductions of $\mathrm{NO}_{\mathrm{x}}, \mathrm{SO}_{2}$ and dust. EEA Technical Report 2013;9. https://www.eea.europa.eu/publications/reducing-air-pollution-from-electricity/\#parent-fieldname-title.

[23] Qin Y, Chan LY. Traffic source emission and street level air pollution in urban areas of Guangzhou, South China (P.R.C.). Atmos Environ. 1993;27B:275-282. DOI: 10.1016/0957-1272(93)90022-X.

[24] Air quality in Europe. Copenhagen: EEA Report 2013;9. www.eea.europa.eu/publications/air-quality-ineurope-2013/download.

[25] Raport o stanie środowiska w województwie łódzkim w 2013 r. (Report on the state of the environment in the Lodz region in 2013). Łódź: Regional Environment Protection Inspectorate; 2014. http://www.wios.lodz.pl/Raport_o_stanie_srodowiska_w_wojewodztwie_lodzkim_w_2013_r,12,8.

[26] https://www.luesa.sachsen-anhalt.de/luesa-web/reload.html?messnetz-luesakarte-aktuell.html.

[27] http://www.wios.lodz.pl/Lodz-Gdanska_16,211,11.

[28] PN-EN 14212:2013-02 (EN 14212:2012). Ambient air - Standard method for the measurement of the concentration of sulphur dioxide by ultraviolet fluorescence. https://sklep.pkn.pl/catalogsearch/result/ $? \mathrm{q}=\mathrm{PN}-\mathrm{EN}+14212 \% 3 \mathrm{~A} 2013-02$.

[29] PN-EN 14211:2013-02 (EN 14211:2012). Ambient air. Standard method for the measurement of the concentration of nitrogen dioxide and nitrogen monoxide by chemiluminescence. http://sklep.pkn.pl/catalogsearch/result/?q=PN-EN+14211\%3A2013-02.

[30] PN-EN 14625:2013-02 (EN 14625:2012). Ambient air. Standard method for the measurement of the concentration of ozone by ultraviolet photometry. https://sklep.pkn.pl/catalogsearch/result/ $? \mathrm{q}=\mathrm{PN}-\mathrm{EN}+14625 \% 3 \mathrm{~A} 2013-02$.

[31] PN-EN 14626:2013-02 (EN 14626:2012). Ambient air. Standard method for the measurement of the concentration of carbon monoxide by non-dispersive infrared spectroscopy. http://sklep.pkn.pl/catalogsearch/result/?q=PN-EN+14626\%3A2013-02.

[32] Google Earth version 7.1.2.2041 (freeware).

[33] Air Quality in Europe - 2017 Report. EEA Report 2017;13. https://www.eea.europa.eu/publications/airquality-in-europe-2017. 